УДК 902/904

https://doi.org/10.24852/2587-6112.2021.2.301.313

\title{
БУСЫ НЕКРОПОЛЯ У ПОС. ЗАОЗЕРНОЕ В СЕВЕРО-ЗАПАДНОМ КРЫМУ: МОРФО-ТЕХНОЛОГИЧЕСКИЙ АНАЛИЗ И ХРОНОЛОГИЯ (ПО МАТЕРИАЛАМ РАСКОПОК 1979-1985 ГГ.) ${ }^{1}$
}

\section{(C) 2021 г. Е.К. Столярова}

Статья посвящена анализу морфологических (форма, декор, цвет и др.) и технологических характеристик бус и привесок, обнаруженных в нескольких погребальных комплексах некрополя у пос. Заозерное в Северо-Западном Крыму, исследованных Крымской археологической экспедицией кафедры археологии МГУ имени М.В. Ломоносова с 1979 по 1985 гг. Украшения некрополя выполнены из стекла, фаянса, полудрагоценных камней (сердолика и горного хрусталя), гагата, янтаря и кости. Полученные результаты говорят о импорте исследованных украшений из районов Передней Азии, Египта и Средиземноморья. Для датирования находок использован главным образом Свод, составленный Е.М. Алексеевой в 1970-е годы, но остающийся до сих пор наиболее значительным изданием, представляющим коллекции бус из различных материалов из многочисленных памятников Северного Причерноморья.

Ключевые слова: археология, бусы, привески, стекло, фаянс, гагат, полудрагоценные камни, янтарь, Северо-Западный Крым, городище «Чайка», эллинизм, римское время.

\section{BEADS FROM A NECROPOLIS NEAR ZAOZERNOE VILLAGE IN NORTH-WESTERN CRIMEA: MORPHOLOGY, MANUFACTURING TECHNOLOGY AND DATING (BASED ON THE FINDS FROM THE EXCAVATIONS OF 1979-1985) ${ }^{2}$}

\section{E. K. Stolyarova}

The paper deals with the study of morphology (shape, decor, color, etc.) and manufacturing technology of beads and pendants found in several burials of a necropolis near the Zaozernoe village in North-Western Crimea. The necropolis was investigated by the Crimean archaeological expedition of the Department of Archaeology, Lomonosov Moscow state University, from 1979 to 1985. The beads and pendants were made of glass, faience, semiprecious stones (carnelian and rock crystal), jet, amber, and bone. The results of the research indicate that these artefacts were imported from the Middle East, Egypt, and the Mediterranean. The catalogue prepared by Ekaterina Alekseeva in 1970s was used for dating the artefacts. This catalogue is still the most significant publication dedicated to collection of beads made of different materials from numerous Northern Black Sea sites.

Keywords: archaeology, beads, pendants, glass, faience, jet, semiprecious stones, amber, North-Western Crimea, Chaika hillfort, Hellenistic period, Roman period.

Некрополь у пос. Заозерное, расположенный в окрестностях г. Евпатории, синхронен находящемуся в 1,5 км от него городищу «Чайка». Городище, основанное Херсонесом, существовало в IV - третьей четверти II в. до н. э. В следующий период жизни поселения - последней четверти II в. до н. э. - первой трети I в. н. э. на его территории была построена небольшая крепость новым населением - поздними скифами. Греки сначала хоронили своих умерших в склепах, которые устраивали в бортах каменоломни, где вели выборку камня для строительства сооружений городища. Затем стали насыпать курганы.
Новое население, поздние скифы, использовали греческие погребальные сооружения для захоронения своих сородичей. Кости прежних покойников сдвигались к стенкам сооружения, и на освободившееся место клали новых усопших. Некрополь подвергался ограблению, поэтому нетронутые захоронения практические отсутствуют. Инвентари и греков, и поздних скифов весьма скромны. Однако в погребениях встречается большое количество разнообразных бус (Попова и др., 2015, c. 76-77).

В данном исследовании учтено 1315 украшений, обнаруженных в нескольких комплек- 
cax некрополя, исследованных Крымской археологической экспедицией кафедры археологии МГУ с 1979 по 1985 гг. ${ }^{1}$ Среди них 1309 бусин и 6 привесок (табл. 1$)^{2}$.

Больше всего находок сконцентрировано в склепе 1984 г. - 1043 экз. (79,3\%). На втором месте по количеству найденных бусин находится склеп 1985 г. - там было найдено
Сравнение этого распределения с другими памятниками, например, с позднескифским склепом № 42 (I в. до н. э. - начало II в. н. э.) из могильника Опушки также показывает преобладание стеклянных и фаянсовых бус $(93,3 \%)$, правда, фаянсовые $(24,6 \%)$ значительно уступают стеклянным (68,7\%) (Храпунов и др., 2009, с. 30, табл. 1).

Таблица 1.

Распределение находок по комплексам

Table 1.

Distribution of the finds by complexes

\begin{tabular}{|c|c|c|c|c|}
\hline \multirow[t]{2}{*}{ Комплекс } & \multicolumn{2}{|c|}{ Бусины } & \multicolumn{2}{|c|}{ Привески } \\
\hline & Кол-во & $\%$ & Кол-во & $\%$ \\
\hline Склеп 1984 г. & 1043 & 79,30 & & \\
\hline Склеп 1985 г. & 112 & 8,50 & & \\
\hline Склеп 1983 г. & 64 & 4,87 & & \\
\hline Курган 40 (1979 г.) & 20 & 1,51 & & \\
\hline Склеп 1979 г. & 18 & 1,37 & & \\
\hline Курган 31a (1980 г.) & 11 & 0,84 & & \\
\hline Курган 32 (1979 г.) & 11 & 0,84 & & \\
\hline Курган 41 (1979 г.) & 11 & 0,84 & 1 & 0,08 \\
\hline Курган 30 (1980-1981 гг.) & 7 & 0,53 & 5 & 0,38 \\
\hline Погребение ребенка (1984 г.) & 6 & 0,48 & & \\
\hline Курган 34 (1982 г.) & 4 & 0,30 & & \\
\hline Курган 11 (1980 г.) & 1 & 0,08 & & \\
\hline Курган 31 (1980 г.) & 1 & 0,08 & & \\
\hline Итого & 1309 & 99,54 & 6 & 0,46 \\
\hline
\end{tabular}

Распределение находок по материалу

Таблийа 2.

Distribution of the finds by material

Table 2.

\begin{tabular}{|c|c|c|c|}
\hline Категория & Материал & Кол-во & $\%$ \\
\hline \multirow[t]{9}{*}{ Бусины } & \multirow[t]{2}{*}{ стекло, из них } & 392 & 29,80 \\
\hline & & 235 & 17,90 \\
\hline & стекло & 157 & 11,90 \\
\hline & фаянс & 889 & 67,60 \\
\hline & гагат & 10 & 0,76 \\
\hline & сердолик & 11 & 0,76 \\
\hline & янтарь & 5 & 0,40 \\
\hline & горный хрусталь & 1 & 0,10 \\
\hline & кость & 1 & 0,10 \\
\hline \multirow[t]{2}{*}{ Привески } & стекло & 5 & 0,38 \\
\hline & фаянс & 1 & 0,10 \\
\hline Итого & & 1315 & 100,0 \\
\hline
\end{tabular}

112 экз. (8,5\%). Из склепа 1983 г. происходит 64 предмета (4,87\%). В остальных комплексах обнаружено от 20 бусин и менее (табл. 1).

Основная масса украшений некрополя - 98\% - сделана из стекла и фаянса, из них фаянсовые составляют две трети (890 экз.; $67,7 \%)$, стеклянные - чуть менее трети (397 экз.; $30,2 \%)$. Оставшиеся $2 \%$ - это бусины из полудрагоценных камней (сердолика и горного хрусталя), гагата, янтаря и кости (табл. 2).
Украшения из фаянса

Самым многочисленным типом среди фаянсовых украшений рассматриваемой коллекции (табл. 3) являются округлые биконические, усеченные с двух сторон - бусины бирюзового цвета (рис. 1: 1), составляющие половину всех фаянсовых украшений (449 экз.; 50,5\%; склеп 1984 г.). Такую же ситуацию преобладания биконических бусин над остальными типами мы видим в склепе № 42 


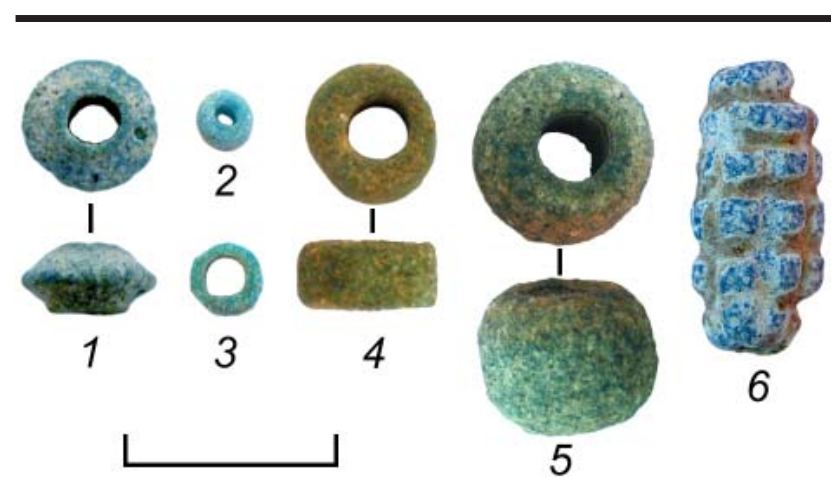

из могильника Опушки (Храпунов и др., 2009, с. 28). Е.М. Алексеевой было учтено всего 318 экз. подобных фаянсовых бусин, что значительно меньше найденных в некрополе. Они были обнаружены в комплексах, датировки которых позволяют отнести их к I-II вв.
Рис. 1. Фаянсовые бусины некрополя у пос. Заозерное.

$$
\begin{gathered}
\text { 1, 2, } 4 \text { - склеп } 1984 \text { г.; } 3 \text { - курган 31a; } \\
5 \text { - курган 34; } 6 \text { - курган } 40
\end{gathered}
$$

Fig. 1. Faience beads from the necropolis near Zaozernoe village. 1, 2, 4- 1984 crypt; 3 - barrow 31a; 5 - barrow $34 ; 6$ - barrow 40

Еще один тип фаянсовых бусин - округлые шаровидные, усеченные с двух сторон (рис. 2: 2). Их обнаружено немногим меньше цилиндрических (200 экз.; 22,5\%). Они также главным образом бирюзовые (рис. 2: 2), все они обнаружены в склепе 1984 г. Есть

Форма фаянсовых украшений

Таблица 3.

Table 3.

Shapes of faience adornments

\begin{tabular}{|c|l|l|c|c|}
\hline \multirow{2}{*}{ Категория } & \multicolumn{2}{|c|}{ Форма } & Кол-во & $\%$ \\
\hline \multirow{3}{*}{ Бусины } & \multirow{2}{*}{ Округлая } & биконическая усеченная дважды & 449 & 50,5 \\
\cline { 3 - 5 } & & цилиндрическая & 234 & 26,3 \\
\cline { 2 - 4 } & шаровидная усеченная дважды & 200 & 22,5 \\
\cline { 2 - 5 } & Бугристая & эллипсоидная усеченная дважды & 5 & 0,5 \\
\cline { 2 - 5 } & Не устанавливается & 1 & 0,1 \\
\hline Привески & В виде амфоры & 890 & 0,1 \\
\hline Итого & & & 100 \\
\hline
\end{tabular}

с наибольшей распространенностью в конце I - начале II в. н. э. (Алексеева, 1975, с. 33, 80, табл. 5: 20, тип 11). Такие же бусы присутствуют и в погребении I-II вв. позднескифского некрополя Красный Маяк на Нижнем Днепре (Дзнеладзе, 2015, с. 192-193, рис. 1: 1).

На втором месте - округлые цилиндрические бусины (рис. 2: 1), они составляют четверть всех фаянсовых украшений (234 экз.; $26,3 \%$ ). Чаще всего они окрашены в бирюзовый цвет (218 экз.; 24,5\%) (рис. 1: 2), редко встречаются сине-зеленые (10 экз.; 1,1\%) (рис. 1: 3), серо-голубые (1 экз.; 0,1\%) и желто-зеленые (1 экз.; 0,1\%) (рис. 1: 4). У четырех бусин цвет не устанавливается. Основная их масса найдена в склепе 1984 г. (217 экз.; 24,6\%). Есть несколько в склепе 1983 г. (8 сине-зеленых и 4 неустановленного цвета). Единичные находки есть в склепе 1985 г. (1 бирюзовая) и в кургане 31a (2 сине-зеленые). Это довольно распространенный тип бусин в Северном Причерноморье: Е.M. Алексеевой учтено более 6000 подобных экземпляров в комплексах с широкими датами VI в. до н. э. - IV в. н. э. Период их наибольшего распространения относится к I-II вв. (Алексеева, 1975 , с. 32,80 , табл. 5: 19, тип 9). единичные сине-зеленые (рис. 1: 5) в склепе 1983 г. и кургане 34. Подобные бусы учтены Е.М. Алексеевой, однако их немного (22 экз.). Ольвийский комплекс, в котором они найдены, не имеет данных для датировки (Алексеева, 1975 , с. 31 , табл. 5: 2, тип. 3б)

Кроме округлых в коллекции присутствуют бугристые эллипсоидные бусины. Их всего 5 экз. (курган 40). Из них одна сине-фиолетовая (рис. 1: 6), другая сине-зеленая, в остальных случаях цвет не устанавливается. По данным Е.М. Алексеевой (ею учтено 75 экз.), самые ранние комплексы с такими бусами относятся к III в. до н. э., есть они и во II в. н. э. Однако наиболее характерный период для этого типа - I в. н. э. (Алексеева, 1975, с. 35, 80, табл. 5: 48, 49, тип 19).

Из фаянса сделана одна привеска в форме амфоры (курган 30). Отметим, что содержащиеся в Своде Е.М. Алексеевой фаянсовые привески в виде стилизованных амфорок представлены типами, совершенно не похожими на наш (Алексеева, 1975, табл. 11: 43, 44; 12: 11).

Касаясь хронологии фаянсовых украшений в целом Е.М. Алексеева выделяет две основные группы: VI-V вв. до н. э. и I в. до н. э. - III в. н. э. Промежуточная группа 


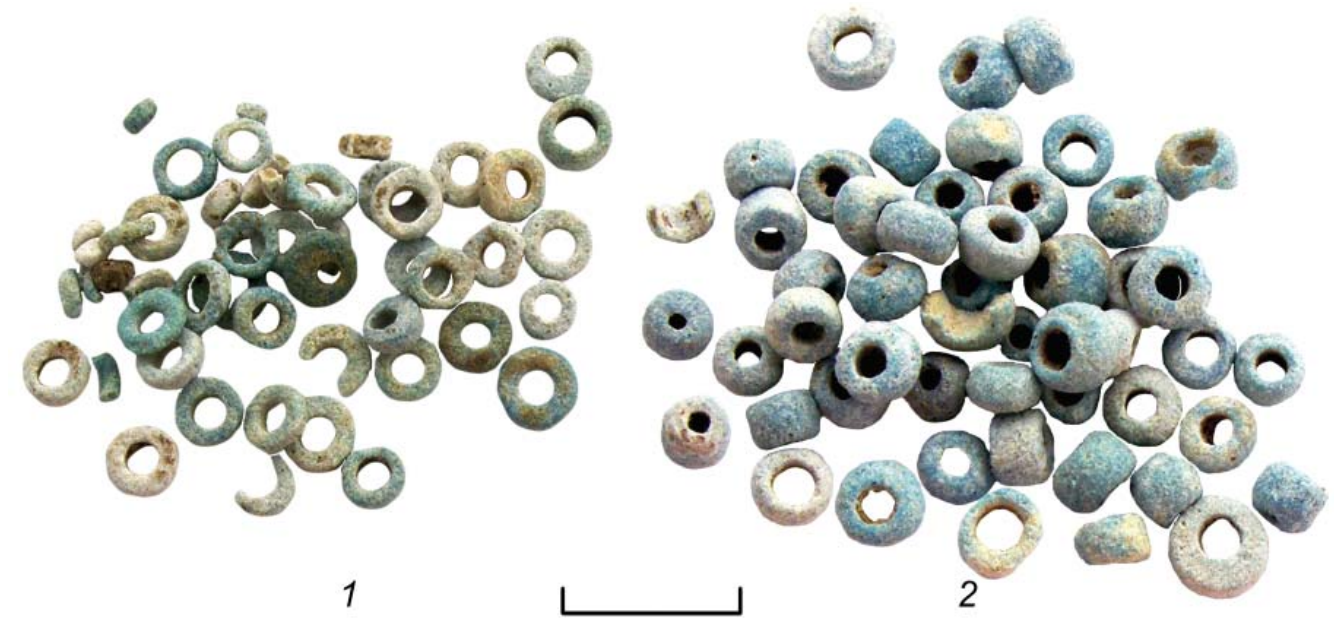

Рис. 2. Фаянсовые бусины из склепа 1984 г. в некрополе у пос. Заозерное

Fig. 2. Faience beads from the 1984 crypt in the necropolis near Zaozernoe village

IV-II вв. до н. э. малочисленна, выделяется нечетко и содержит типы, близкие поздней группе, пик в распространении которых относится к I в. н. э., а наплыв их начинается уже со второй половины I в. до н. э. (Алексеева, 1975, c. 28).

\section{Украшения из стекла}

Из 397 стеклянных украшений почти 60\% (235 экз.; 59,2\%) составляют бусины с металлической фольгой (табл. 4). Доля таких бусин среди всех рассматриваемых украшений некрополя также велика - почти 18\% (табл. 2). Исследование склепа № 42 из могильника Опушки показывает картину, сходную с нашей: там бусы с фольгой составляют $24,5 \%$ (Храпунов и др., 2009, с. 30, табл. 1).

Во всех случаях сохранность бусин не дает возможность установить материал фольги, была ли она серебряной или золотой. То же касается и цвета стекла: у большей части бусин (168 экз.; 71,5\%) цвет основы и покровного слоя, закрывавшего фольгу, не определяется. Среди остальных в основном бусины из бесцветного прозрачного стекла (64 экз.; из двух способов изготовления бус с фольгой, выделенных Е.М. Алексеевой. Бусы, сделанные по этой схеме, известны и в эпоху эллинизма, и в римское время (Алексеева, 1978, с. 27).

Основная форма бусин с фольгой - округлые эллипсоидные, усеченные с двух сторон, их немногим меньше половины (105 экз.; $44,7 \%$ ). Часть из них имеет шейки (57 экз.) (рис. 3: 1), такие бусины происходят только из склепа 1984 г., одна бусина с валиками (курган 34) (рис. 3: 2). Бусы без шеек (рис. 3: 3) обнаружены в основном в склепах 1985 (23 экз.) и 1983 гг. (15 экз.), совсем немного их в склепе 1984 г. (6 экз.) и в курганах 31 а (2 экз.) и 34 (1 экз.). По данным Е.М. Алексеевой, в Северном Причерноморье аналогичные бусы без шеек (ею учтено 312 экз.) имеют широкую датировку - III в. до н. э. - III в. н. э. (Алексеева, 1978, с. 30, 89, табл. 26: 12, тип 2а). Бусы же с шейками (учтено 67 экз.) (Алексеева, 1978 , с. $30,89$. табл. $26: 11,13,14$, тип 26$)$ и с валиками (учтено 105 экз.) (Алексеева, 1978,

Форма стеклянных бусин с металлической фольгой

Таблица 4.

Table 4.

Shapes of glass beads with metal foil

\begin{tabular}{|c|c|c|c|c|}
\hline Категория & \multicolumn{2}{|r|}{ Форма } & Кол-во & $\%$ \\
\hline \multirow[t]{4}{*}{ Бусы } & \multirow{2}{*}{ Округлая } & Эллипсоидная усеченная дважды & 105 & 44,7 \\
\hline & & Шаровидная усеченная дважды & 66 & 28,0 \\
\hline & Ребристая & Шаровидная усеченная дважды & 53 & 22,6 \\
\hline & Бугристая & Шаровидная усеченная дважды & 11 & 4,7 \\
\hline \multicolumn{3}{|l|}{ Итого } & 235 & 100,0 \\
\hline
\end{tabular}

27,3\%), а также по одной из желтого, бежевого и бледно-фиолетового.

Эти бусы всегда выполнены из тянутой трубочки, а покровный слой нанесен жидким стеклом, что соответствует первому с. 32,89 , табл. $26: 24,30$, тип 22,23 ) относятся только к римскому времени.

Вторая группа - округлые шаровидные, их немногим больше четверти (66 экз.; 28\%). Сюда входят бусы как усеченные с двух сторон, 

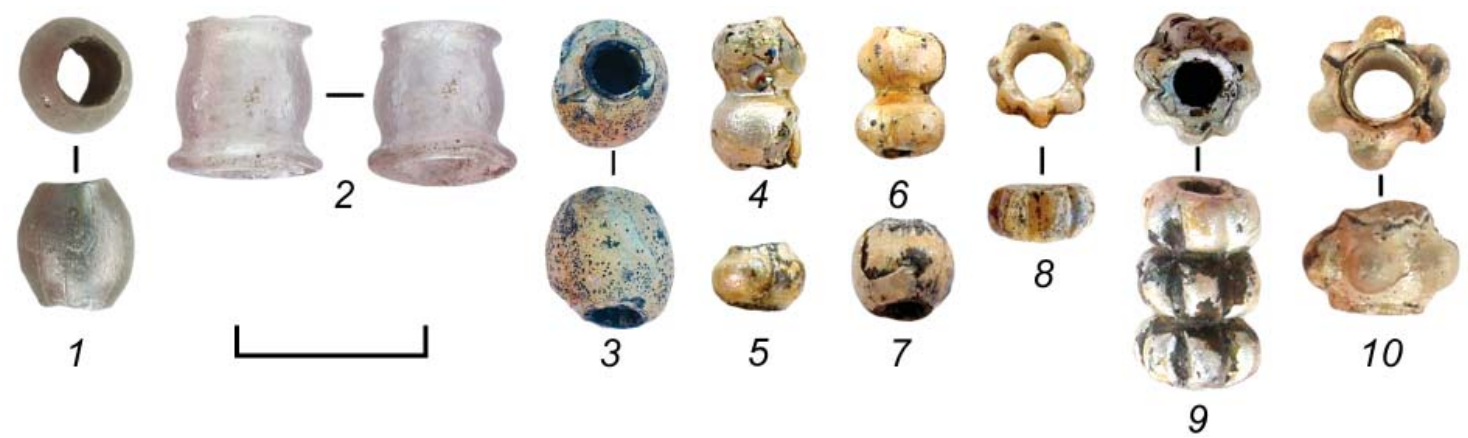

Рис. 3. Стеклянные бусины с металлической фольгой из некрополя у пос. Заозерное. 1, 4, 8, 9 - склеп 1984 г.; 2 - курган 34; 3 - курган 31a; 5-7 - склеп 1985 г.; 10 - курган 32

Fig. 3. Glass beads with metal foil from the necropolis near Zaozernoe village. 1, 4, 8, 9 - 1984 crypt; 2 - barrow 34; 3 - barrow 31a; 5-7 - 1985 crypt; 10 - barrow 32

так и бусы-шарики. Среди первых есть двухчастные экземпляры, таких 7 шт. (рис. 3: 4). Некоторые бусы как одинарные (6 экз.), так и сдвоенные (2 экз.) имеют шейки (рис. 3: 5, 6), все они найдены в склепе 1985 г. Бусы без шеек (рис. 3: 7) происходят из склепов 1984 и 1985 гг., только одна бусина обнаружена в кургане 34. По мнению Е.М. Алексеевой, этот тип бусин представляет один из наиболее распространенных в Северном Причерноморье. В частности, ею учтено 1755 бусин без шеек, наиболее характерных для эпохи эллинизма, но также встречающихся и в первые века н. э. (Алексеева, 1978, с. 29, 89, табл. 26: 2, 3, тип 1a), и более 3500 бусин с шейками, периодом распространения которых является римское время (Алексеева, 1978, с. 29, 89, табл. 26: 4-8, тип 1б).

Следующий тип - ребристые шаровидные, усеченные с двух сторон (рис. 3: 8). Их чуть меньше, чем предыдущих - 53 экз. (22,6\%; склеп 1984 г.). Среди них одна трехчастная (рис. 3: 9). По данным, приводимым Е.М. Алексеевой, такие бусы (учтено 167 экз.) наиболее характерны для I в. до н. э. - I в. н. э., но могут встречаться как в более раннее, так и в более позднее время (Алексеева, 31, 89, табл. 26: 49, 50, тип 10).

Последняя группа - это бугристые шаровидные, усеченные с двух сторон (рис. 3: 10), таких всего 11 экз. (4,7\%). 9 бусин обнаружены в кургане 32, еще две - в склепе 1985 г. В Своде Е.М. Алексеевой учтено 116 таких бусин, основным периодом бытования которых является эпоха эллинизма, особенно часто они встречаются во II в. до н. э. Изредка подобные бусины обнаруживают в комплексах I в. н. э. (Алексеева, 1978, с. 31-32, 89, табл. 26: 53, тип 15).

Таким образом, среди бусин с фольгой количественно преобладают округлые украшения (типы 1 и 2 по Е.М. Алексеевой), составляющие почти три четверти таких находок (72,7\%). Основная их масса обнаружена в склепах 1984 (86 экз.; 36,6\%) и 1985 гг. (65 экз.; 27,7\%). В склепе 1983 г. найдено 15 экз., в курганах 31а и 34 - по 2-3 бусины. Преобладание таких типов характерно для позднескифских склепов I в. до н. э. - I в. н. э. (Храпунов и др., 2009, с. 28).

По данным Е.М. Алексеевой, бусы с фольгой появляются в Северном Причерноморье с III в. до н. э., существуют и в эллинистическое, и в римское время. При этом к эпохе эллинизма относятся преимущественно одиночные бусины без шеек, а к римскому периоду цепи бусин и одиночные с шейками и валиками (Алексеева, 1978, с. 28-29). Среди рассмотренных нами можно отметить значительное преобладание одиночных бусин без шеек (163 экз.; 69,4\%) над сдвоенными, строенными и одиночными с шейками и валиками (72 экз.; $30,6 \%)$.

Обратимся к остальным стеклянным украшениям некрополя (табл. 2). Их немного, всего 162 экз. (из них 5 привесок), что составляет $12,3 \%$ от всей коллекции. Для сравнения: в склепе № 42 из могильника Опушки стеклянные украшения (без учета бусин с металлической фольгой) насчитывают 44,2\% (Храпунов и др., 2009, с. 30, табл. 1).

Рассмотрим бусины из одноцветного стекла и многоцветные с накладным декором вместе. Самыми многочисленными из них являются бусы с основой из сине-фиолетового стекла. Они составляют почти треть всех стеклянных украшений (52 экз.; 32,1\%). Среди них в основном округлые разных форм. Наиболее часто встречаются усеченное-конические бусы из тянутой палочки (рис. 4: 1), составляющие половину сине-фиолетовых бусин (26 экз.). Изредка их украшают накладные белые полосы, начинающиеся у одного отверстия и не достигающие другого (3 экз.) 


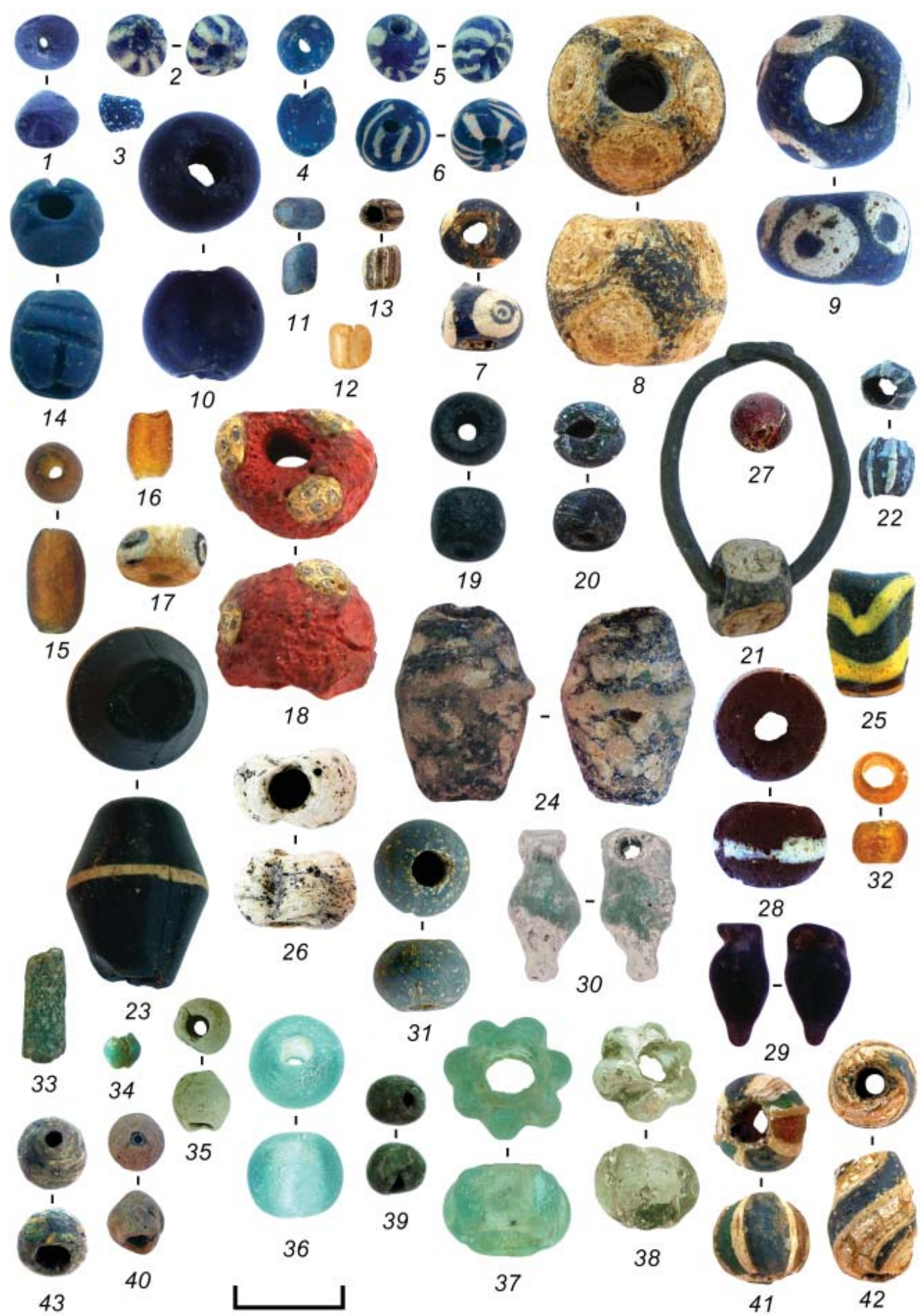

Рис. 4. Стеклянные бусины некрополя у пос. Заозерное. 1, 9, 34 - склеп 1979 г.; 2, 30, 33, 40 - курган 41; 3, 24 , 35, 39, 43 - курган 40; 4-6, 21, 23, 29 - курган 30; 7, 11-13, 18, 31, 32, 41, 42 - склеп 1984 г; 8, 16, 17, 20, 26, 27, 36 - склеп 1985 г.; 10, 22, 28 - курган 31a; 14, 15, 19, 38 - склеп 1983 г.; 25 - курган 31;

37 - погребение ребенка 1984 г.

Fig. 4. Glass beads from a necropolis near Zaozernoe village. 1, 9, 34 - 1979 crypt; 2, 30, 33, 40 - barrow 41; 3, 24, 35, 39, 43 - barrow 40; 4-6, 21, 23, 29 - barrow 30; 7, 11-13, 18, 31, 32, 41, 42 - 1984 crypt; 8, 16, 17, 20, 26, 27, 36crypt of $1985 ; 10,22,28$ - barrow $31 \mathrm{a} ; 14,15,19,38$ - 1983 crypt; 25 - barrow 31 ;

37 - 1984 child's burial of 1984

(рис. 4: 2). Им близки одноцветная бусина шаровидной, усеченной с двух сторон формы также из тянутой палочки (рис. 4: 3) и яйцевидные бусы (4 экз.), три из которых изготовлены из палочки (рис. 4: 4), среди них одна с аналогичным декором (рис. 5: 5), а четвертая сварена из кусочков стекла, декорирован- ных накладными белыми нитями (рис. 4: 6). Найдены эти бусы в курганах 30, 32, 40, 41 и склепе 1979 г.

Аналогичные бусины приведены в Своде Е.М. Алексеевой и отнесены к типам 42 (одноцветное стекло) и 192а (многоцветное стекло) (Алексеева, 1978, с. 59, 62). Бусы без декора 
(тип 42) обнаружены в комплексах IV-II вв. до н. э. (учтено 50 экз.) и только одна бусина датирована концом I - началом II в. н. э. (Алексеева, 1978, с. 66, табл. 33: 8, тип 42). Бусины с полосами (тип 192а) имеют более узкую дату - III в. до н. э. (учтено 39 экз.), только две предположительно относятся к римскому времени (Алексеева, 1978, с. 43, 91, табл. 27: 89, тип 192а).

На втором месте среди рассматриваемых сине-фиолетовых бусин - шаровидные, усеченные с двух сторон (16 экз.), некоторые из которых (4 экз.) имеют декор в виде глазков сине-фиолетового и белого цветов. Одна из декорированных украшена тремя мозаичными глазками (рис. 4: 7), две - шестью (рис. 4: 8) и одна - семью глазками (рис. 4: 9) из накладных капель. Недекорированные бусины изготовлены главным образом из трубочки (рис. 4: $10)$, есть единичные навитые и сваренные из кусков. Глазчатые же бусы выполнены только при помощи навивки. Бусы без декора обнаружены в кургане 31а и склепах 1983, 1984 и 1985 гг. Бусина с тремя глазками происходит из склепа 1984 г., с семью - из склепа 1985 г. Бусы, украшенные шестью глазками, найдены в кургане 41 и склепе 1979 г. В последнем случае бусина была найдена надетой на бронзовую проволоку, являясь, по-видимому, частью височного кольца.

Сине-фиолетовые шаровидные, усеченные с двух сторон бусы без декора известны на территории Северного Причерноморья в течение длительного периода, начиная с эпохи эллинизма и вплоть до позднеримского времени. При этом бусы из трубочки наиболее характерны для I-II вв. (Алексеева, 1978, c. $65-65$, табл. $33: 1$, тип 15).

Бусы с накладными мозаичными глазками появляются в Северном Причерноморье в конце IV в. до н. э., известны они и в римское время (Алексеева, 1975, с. 56). Согласно Своду Е.М. Алексеевой, бусы, украшенные тремя подобными глазками (учтено 15 экз.), известны с IV в. до н. э. по II в. н. э. (Алексеева, 1975 , с. 62,85 , табл. 15: 36 , тип 33 т). Бусина, очень близкая рассматриваемой, присутствует в кургане третьей четверти III в. до н. э. могильника у с. Глиное на Нижнем Днестре (Синика, Тельнов, 2018, с. 234, 236, рис. 9, и).

Бусы с глазками из накладных капель известны на территории Северного Причерноморья уже в VI-IV вв. до н. э., они продолжают бытовать и в первые века н. э. Аналогии же нашим бусинам с шестью глазками в этой технике Е.М. Алексеева относит к IV-II вв. до н. э., особенно к IV-III вв. до н. э. (ею учтено 30 экз.). Хотя по одной такой бусине обнаружено в двух комплексах Пантикапея с иными датами: второй половины V - IV в. до н. э. и II-I вв. до н. э. (Алексеева, 1975, с. 66, 86, табл. 15: 6, 7, тип 54в). К сожалению, бусы, украшенные семью глазками из накладных капель (известны одна из Пантикапея и три из Кеп), не имеют дат (Алексеева, 1975, с. 67, 87, табл. 15: 13, тип 66б).

В группе сине-фиолетовых присутствуют бусы цилиндрической формы, выполненные членением тянутой трубочки, по диаметру тулова (3-5 мм) относящиеся к бисеру, традиционно называемому рубленым (4 экз.) (рис. 4: 11). Помимо сине-фиолетового в некрополе присутствуют желтый бисер (4 экз.) (рис. 4: 12) и одна бисерина из черного стекла (рис. 4: 13). Все, за исключением одной желтой, происходящей из склепа 1983 г., были найдены в склепе 1984 г. Этот тип бусин был чрезвычайно распространен в Северном Причерноморье в течение очень долгого времени. Он появляется в III в. до н. э. и бытует до IV в. н. э., достигая наибольшей популярности во II-I вв. до н. э. (Алексеева, 1978, с. 62, 72, табл. 33: 71, тип 166).

Кроме округлых в группе рассматриваемых сине-фиолетовых бусин присутствует одна в форме скарабея (склеп 1983 г.) (рис. 4: 14). Находки подобных украшений в Северном Причерноморье редки - в Своде Е.М. Алексеевой указано всего 6 экз. Из них датированы только две из красно-коричневого и светло-зеленого непрозрачного стекла, обнаруженные в комплексе второй половины I - первой половины II в. н. э. могильника на территории совхоза № 10 около Инкермана (Алексеева, 1978, с. 73, табл. 34: 18, 19, тип 183).

Второе место в количественном отношении занимают одноцветные бусы из бежевого стекла (16 экз.), составляющие 9,8\%. Все они округлой эллипсоидной, усеченной дважды формы. Большая их часть сделана из тянутой трубочки (склеп 1983 г.) (рис. 4: 15), одна - из палочки (склеп 1985 г.) (рис. 4: 16). Им близка единичная бусина из оливкового стекла такой же формы из трубочки (погребение ребенка). Среди бусин, собранных в Своде Е.М. Алексеевой, ближайшим им может быть тип 23, правда, рассматриваемые нами бусины, кроме оливковой, не имеют шеек. Е.М. Алексеевой было учтено 42 экз., происходящих из комплексов второй половины I в. до н. э. - 
III в. н. э. (Алексеева, 1978, с. 65, табл. 33: 5, тип 23).

Чуть менее многочисленны бусины из черного, пурпурного и красно-коричневого стекла. Доля каждого типа по 7-8\%.

Красно-коричневые ${ }^{3}$ бусины всегда округлые шаровидные, усеченные с двух сторон, выполненные обертыванием, из тянутой палочки, редко трубочки. Большая их часть украшена накладными мозаичными глазками разных цветов.

Похожие на красно-коричневые бусы без декора (4 экз.; склепы 1984 и 1985 гг.) есть в Своде Е.М. Алексеевой (учтено более 960 экз.), они датированы IV в. до н. э. - III в. н. э. с преимущественным распространением в IIII вв. Бусы, сделанные из тянутых трубочек, связаны с комплексами только первых веков н. э. (Алексеева, 1978, с. 63, табл. 33: 1, тип 3).

Для красно-коричневых бусин, украшенных глазками, также есть аналогичные в Своде Е.М. Алексеевой. Например, похожие на бусины с тремя концентрическими глазками из сине-фиолетового и белого стекла (4 экз.; склеп 1984 г. и погребение ребенка) являются распространенным типом (учтено 73 экз.), встречающимся во всех рассмотренных Е.М. Алексеевой памятниках и датирующимся довольно широко - с IV в. до н. э. по III в. н. э., но периодом его наибольшей популярности является II в. до н. э. - I в. н. э. (Алексеева, 1975, с. 60, 84, табл. 14: 71, 102, 103, тип 27 г, д). Бусины с такими же глазками, но из пурпурного или коричневого и белого стекла (4 экз.; склепы 1983, 1985 гг. и погребение ребенка) (рис. 4: 17) довольно редки (учтено 3 экз.) и отнесены к III в. до н. э. - І в. н. э. (Алексеева, 1978, с. 60, 84, табл. 14: 83, тип 27и). Аналогии бусине (склеп 1984 г.), украшенной глазками, названными Е.М. Алексеевой розеттами (рис. 4: 18), относятся ко второй половине IV - III в. до н. э. (учтено 3 экз.) (Алексеева, 1978, с. 55, 95, табл. 27: 103, тип 378).

Черные бусы из рассматриваемых комплексов некрополя наиболее разнообразны по форме, но чаще всего среди них также встречаются округлые шаровидные, усеченные с двух сторон. Они выполнялись навивкой (рис. 4: 19), из тянутой трубочки или палочки (рис. 4: 20). Одна из них, украшенная тремя цветными пятнами (белым и красно-коричневым, цвет третьего не установлен), являлась частью височного кольца (рис. 4: 21).

Одноцветные черные бусины вышеназванной формы (5 экз.; курган 31а, склепы
1983, 1985 гг.) относятся к одним из наиболее распространенных - в Своде Е.М. Алексеевой учтено 1359 экз. Большая их часть датируется II-III вв. н. э. При этом навитые бусины отмечены в комплексах конца VI - II в. до н. э. и I-IV вв. н. э., а бусы из трубочки - только в комплексах I - первой половины III в. (Алексеева, 1978, с. 62-63, табл. 33: 1, тип 1).

Бусы разных цветов с пятнами отмечены в Северном Причерноморье с VI в. до н. э. по IV в. н. э., но до рубежа эр они редки. Среди них черные являются наиболее распространенными (Алексеева, 1975, с. 50-51). Бусине, выполненной навивкой, украшенной разноцветными пятнами и надетой на проволоку (курган 30), точной аналогии в Своде Е.М. Алексеевой не найдено. Близкой является бусина с пятнами других цветов. Она обнаружена в Херсонесе и не имеет точной даты (Алексеева, 1975, с. 57, табл. 12: 46, тип 2).

Кроме шаровидных в группе черных бусин есть эллипсоидные и биконические, усеченные с двух сторон, декорированные накладными полосами и пятнами. Следует отметить, что бусы как с поперечными, так и с продольными полосами известны на территории Северного Причерноморья с IV в. до н. э. по IV в. н. э., но основная масса зарождается во второй половине III до н. э., известна во II в. до н. э. и существует до I в. н. э. (Алексеева, 1978, c. 34-35).

Аналогии эллипсоидной бусине из трубочки с продольными белыми полосами (курган 31a) (рис. 4: 22), собранные Е.М. Алексеевой (учтено 37 экз.), происходят из комплексов главным образом II-I вв. до н. э., но продолжают встречаться и в I-II вв. н. э. (Алексеева, 1978 , с. 43 , 91, табл. 27: 85, тип 190б).

Точные аналогии еще одной эллипсоидной бусине, но сделанной однократным обертыванием и украшенной несколькими поперечными полосами (склеп 1985 г.), в Своде Е.М. Алексеевой не обнаружены. Наиболее близкими являются бусы из пурпурного стекла цилиндрической формы с таким же декором (3 экз.), датированные второй половиной II в. до н. э. - первой половиной I в. н. э. (Алексеева, 1978, с. 42, 90, табл. 27: 30, тип 180a).

Ближайшей аналогией навитой биконической бусине, декорированной белой поперечной полосой (курган 30) (рис. 4: 23), является бусина из Свода Е.М. Алексеевой (правда, она украшена желтой полосой), датированная III - первой половиной II в. до н. э. (Алексеева, 1978, с. 44, 91, табл. 28: 8, тип 203б). 
Второй биконической навитой бусине, украшенной белой поперечной полосой и беспорядочными пятнами белого, желтого и желто-зеленого цветов (курган 40) (рис. 4: 24), в том же Своде нашлась точная аналогия. Она происходит из культурного слоя Танаиса (Алексеева, 1978, с. 54, табл. 32: 31, тип 348).

Среди черных бусин, помимо округлых, найдена одна ребристая шаровидная с двумя дольками, украшенная накладной спиралью ${ }^{4}$ (погребение ребенка), и граненая с желтыми зигзагами (фрагментированная) (курган 31) (рис. 4: 25). Для последней нашлись точные аналогии в Своде Е.М. Алексеевой (15 экз.), относящиеся к IV-III вв. до н. э. (Алексеева, 1978 , с. 49, 92, табл. 31: 6, тип 276б). Данный тип является одним из наиболее характерных для этого периода (Алексеева, 1978, с. 38).

Комплексы, содержащие ребристые (из двух долек) шаровидные, усеченные с двух сторон бусы с накладной белой спиралью, ограничены Е.М. Алексеевой III в. до н. э. - I в. н. э. (учтено 9 экз.). В целом такие бусы, по мнению Е.М. Алексеевой, относятся к периоду позднего эллинизма - рубежу эр (Алексеева, 1978, с. 35, 45, 91, табл. 28: 59, тип 223). Это подтверждается, например, материалами некрополя Беляуса, где такие бусы происходят в основном из захоронений II-I вв. до н. э. и изредка из погребений I в. н. э. (Дашевская, 2014).

Группу украшений из пурпурного стекла рассматриваемой коллекции представляют не только бусины (9 экз.), но и привески (3 экз.). Форма пурпурных бусин в основном округлая шаровидная, усеченная с двух сторон. Встречены одноцветные бусины из трубочки (5 экз.; склеп 1985 г.) (рис. 4: 27), одна сваренная из кусков (склеп 1984 г.) и еще одна декорированная накладной поперечной белой полосой (курган 31a) (рис. 4: 28). Кроме того, есть две эллипсоидные, усеченные дважды (склеп 1985 г.). Они декорированы накладными поперечными или продольными полосами белого цвета.

Е.М. Алексеева относит бусы из одноцветного пурпурного стекла округлой шаровидной, усеченной дважды формы к типам, встречающимся с III в. до н. э. по III в. н. э. (ею учтено 439 экз.), но наибольшей популярности они достигают в период II-I вв. до н. э., а бусы, сделанные из тянутых трубочек, появляются только с I в. н. э. (Алексеева, 1978, с. 63, табл. 33: 1, тип 4).

Аналогии декорированной поперечной полосой пурпурной бусине вышеназван- ной формы встречаются главным образом в комплексах I-II вв. н. э. (учтено 9 экз.), и только одна - в комплексе из Фанагории II в. до н. э. (Алексеева, 1978, с. 44, 91, табл. 28: 2, тип 201).

Бусине с таким же декором, но эллипсоидной, усеченной дважды формы близка аналогия из Пантикапея без точной даты, но изготовленная из черного стекла (Алексеева, 1978, с. 44,91 , табл. 28: 10, тип 203a).

Аналогии эллипсоидной бусине с продольными белыми полосами, собранные Е.M. Алексеевой (ею учтено 37 экз.), происходят из комплексов главным образом II-I вв. до н. э., но продолжают встречаться и в I-II вв. н. э. (Алексеева, 1978, с. 43, 91, табл. 27: 86, тип 190б).

Привески из пурпурного стекла имеют форму амфор (3 экз.; курган 30) (рис. 4: 29). Среди анализируемых украшений некрополя присутствуют еще две привески аналогичной формы: у одной цвет не установлен (курган 30), другая из серо-голубого стекла (курган 41) (рис. 4: 30). По сведениям Е.М. Алексеевой, привески в виде амфор наиболее характерны для III - I вв. до н. э. (Алексеева, 1978, c. 62). Однако для рассматриваемых находок точных аналогий найти не удалось. В Своде Е.М. Алексеевой есть похожие, но немного других пропорций и цветов. Они происходят главным образом из комплексов IV-II вв. до н. э. (11 экз.), несколько найдены в комплексах первых веков н. э. (3 экз.) (Алексеева, 1978, с. 74, табл. 34: 40, тип 193д).

Небольшую группу в рассматриваемой коллекции составляют бусины из бирюзового стекла (10 экз.; 6,1\%). Все они округлые шаровидные, усеченные дважды, сделанные из тянутой трубочки (склепы 1984, 1985 гг.) (рис. 4: 31). В Северном Причерноморье по данным Е.М. Алексеевой (ею учтено 77 экз.) такие типы характерны для I-II вв. (Алексеева, 1978, с. 66, табл. 33: 4, тип 31).

Еще один тип - бусины из желтого стекла округлой шаровидной, усеченной с двух сторон формы из тянутой трубочки (4 экз.; склеп 1984 г.) (рис. 4: 32). В Своде Е.М. Алексеевой учтены более 200 экз. подобных бусин. Они известны непрерывно с I в. до н. э. по II в. (Алексеева, 1978, с. 63-64, табл. 33: 1, тип 6).

Остальные типы бусин единичны. Длинная округлая цилиндрическая бусина из трубочки из непрозрачного сине-зеленого стекла (курган 41) (рис. 4: 33) находит себе аналогии в Своде Е.М. Алексеевой, где учтено 45 таких же экз., относящихся к I-III вв. (Алексеева, 1978, с. 
67, табл. 33: 11, тип 66). Округлые усеченно-конические и биконические, усеченные с двух сторон бусины из палочки из такого же стекла (2 экз.; склеп 1979 г.) (рис. 4: 34) не так часто отмечены в Своде Е.М. Алексеевой всего 9 экз., датированных IV-III вв. до н. э. (Алексеева, 1978, с. 66, табл. 33: 8, тип 41). Близкие округлой биконической бусине из палочки также из сине-зеленого, но прозрачного стекла (курган 40) (рис. 4: 35), согласно Своду Е.М. Алексеевой, редки (учтено 6 экз.). Они обнаружены только в одном комплексе могильника на территории совхоза № 10 около Инкермана, датированного первыми веками н. э. (Алексеева, 1978, с. 66, табл. 33: 8 , тип 40). В отличие от них подобные двум округлым шаровидным из такого же стекла бусинам (склеп 1985 г.) (рис. 4: 36), были довольно популярны в Северном Причерноморье: в Своде Е.М. Алексеевой таких учтено 1089 экз., бытующих с III в. до н. э. до III в. н. э. (Алексеева, 1978, с. 64, табл. 33: 1, тип 11). Однако сюда включены бусы, сделанные разными способами (навивкой, вытягиванием и т. д.) и имеющие в зависимости от этого разную датировку. Рассматриваемые нами бусы, сделанные обертыванием и имеющие гладкие края и поперечную структуру ядра, относятся к первым векам н. э.

Из бледно-зеленого стекла присутствуют три шаровидные бусины из трубочки: одна округлая (склеп 1984 г.) и две ребристые (погребение ребенка) (рис. 4: 37). Похожие округлые есть в Своде Е.М. Алексеевой (ею учтено 70 экз.), относятся они к I-III вв. н. э. (Алексеева, 1978, с. 64, табл. 33: 3, тип 10).

Кроме ребристой из бледно-зеленого стекла есть такая же ребристая, но из бледного желто-зеленого стекла (склеп 1983 г.) (рис. 4: 38). Для ребристых бусин этих цветов в Своде точной аналогии не нашлось, наиболее близки им бусы из бесцветного прозрачного стекла (Алексеева, 1978, с. 71, табл. 33: 50, тип 152). Данный тип (всего учтено 26 экз.) включает бусы разные по форме, размеру, по характеру долек и по технологии их нанесения. В зависимости от этого бусы распределены по разным периодам. Рассматриваемые нами, вероятнее всего, должны быть датированы III-I вв. до н. э.

Из желто-зеленого стекла выполнена еще одна бусина: округлая шаровидная из палочки, декорированная накладными желтыми полосами (курган 40) (рис. 4: 39). Точной аналогии ей в Своде Е.М. Алексеевой не нашлось, но очевидно, что она близка таким же полоса- тым бусинам, но из сине-фиолетового стекла (тип 192а), основная масса которых датирована III в. до н. э.

Для пяти бусин из палочек усеченно-конической и биконической формы, цвет стекла которых не устанавливается (курганы 40, 41) (рис. 4: 40), тип по Своду Е.М. Алексеевой определить невозможно. Однако они близки сине-фиолетовым и сине-зеленым бусинам аналогичных форм из проколотых палочек (типы 41 и 42), датированных IV-III вв. до н. э. и IV-II вв. до н. э. соответственно.

Рассмотрим многоцветные бусины, у которых основа и декор выполнялись одновремен$\underline{\text { но }}$ (14 экз.). Большую их часть (13 экз.; склепы 1984, 1985 гг.) составляют округлые шаровидные и эллипсоидные формы, сваренные из нескольких положенных продольно полос сине-фиолетового, зеленого, желтого прозрачного и белого непрозрачного стекла (9 экз.) (рис. 4: 41). Последний является не отдельной полосой белого стекла, а сильно разогретым краем цветной полосы, который кристаллизовался и потерял цвет. В некоторых случаях полосы закручены и превращены в спирали (4 экз.) (рис. 4: 42). Такая техника носит название ленточного стекла и известна не столько в бусах, сколько в сосудах различных форм: чашах, бутылках и пиксидах. Изготавливали их, как принято считать, в Александрии в конце I в. до н. э. - первой половине I в. н. э. Найденные в некрополе бусины в этой технике можно считать выполненными из остатков стекла, которое шло на производство таких сосудов.

В Своде Е.М. Алексеевой учтено 12 подобных бусин с продольными полосами, они отнесены к I в., но, возможно, заходят и во II в. н. э. (Алексеева, 1978, с. 35, 43, 91, табл. 27: 90, 91, тип 194, 195). Бусы же со спиралевидными полосами (учтено 45 экз.) появляются в конце I в. до н. э., массово распространяются в I-II вв. и доживают до III в. н. э. (Алексеева, 1978, с. 47, 92, табл. 29: 69-71, тип 249).

Оставшуюся бусину усеченно-конической формы (курган 40) можно отнести в группу миллефиори, которая в отличие от вышеназванных предполагала сварку не полос, а кусков стекла различной формы. Она была сварена из мозаичных кусочков желто-зеленого и желтого цветов, проколота острием и обкатана (рис. 4: 43). В Своде Е.М. Алексеевой аналогии ей не найдены.

Таким образом, можно говорить, что самыми популярными формами украшений из 
стекла (без учета бус с металлической фольгой) рассматриваемых комплексов некрополя у пос. Заозерное были округлые, составляющие почти 92\% (149 экз.: 91,9\%). Среди них наиболее многочисленные - шаровидные, усеченные с двух сторон (69 экз.; 42,6\%) и усеченно-конические (31 экз.; 19,1\%).

Среди технических приемов наиболее часто отмечены украшения, сделанные из тянутой трубочки - их 64 экз., что составляет почти 40\% (39,51\%). Почти столько же предметов из тянутой палочки - 54 экз. (33,3\%). Значительно меньше бусин, выполненных сваркой (17 экз.; 10,49\%) и навивкой (15 экз.; 9,26\%). Еще меньше бусин, изготовленных обертыванием полосы - всего 8 шт. (4,94\%). Всего одна бусина сделана литьем.

Массовое изготовление бусин из трубочек возникает в первые века н. э. на территории Передней Азии (Щапова, 1983, с. 127). Однако начало этого производства датируется более ранним временем. В частности, изготовление бусин с металлической фольгой, тоже производившихся из тянутых трубочек, относится к III в. до н. э. и локализуется на о. Родос (Weinberg, 1983). Использование тянутой палочки, приемов навивки, обертывания и литья для изготовления бусин возникло еще в более раннее время. Мозаичная техника также имеет долгую историю. Первые предметы в этой технике появились в середине II тыс. до н. э. в Месопотамии. Позднее оттуда через Финикию и Сирию эта технология проникла в Египет эллинистического и римского времени (Щапова, 1983, с. 113). Видимо, там же и тогда же была освоена и техника ленточного стекла.

\section{Бусы из гагата}

Среди рассматриваемых бусин присутствует всего 10 гагатовых (склеп 1983 г.). Все они округлой цилиндрической формы (рис. 5: 1). Согласно данным Е.М. Алексеевой, этот тип - короткоцилиндрические нарезки - является самым многочисленным в Северном Причерноморье. В Своде из всех учтенных 7416 гагатовых украшений 5026 экз. составляют бусы аналогичные нашим (Алексеева, 1978 , с. 14,85 , табл. 20: 41, тип 27a). Этот тип бусин был популярен во все времена - с III в. до н. э. вплоть до IV в. н. э., однако основное количество комплексов с такими бусами датированы I-II вв. н. э., а к эллинистическому времени относится немного погребений. При этом основная масса бусин раннего времени сосредоточена на востоке Причерноморья: в Пантикапее, Фанагории, Кепах, Тирамбе, Горгиппии, Танаисе. Кроме того, бусины

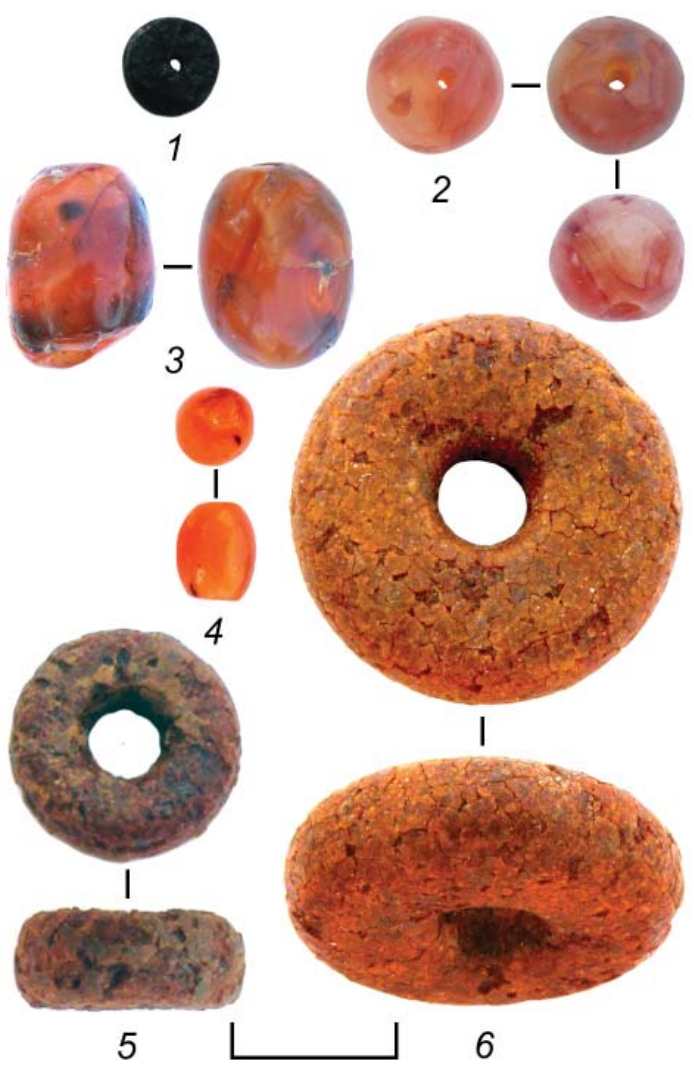

Рис. 5. Бусины некрополя у пос. Заозерное. 1, 5 - склеп 1983 г;; 2 - курган 30; 3 - курган 31а; 4 - склеп 1984 г.; 6 - склеп 1985 г. 1 - гагат; 2-4-сердолик; 5, 6-янтарь

Fig. 5. Beads from the necropolis near Zaozernoe village. 1, 5 - 1983 crypt; 2 - barrow 30; 3 - barrow 31a; 4 - 1984 crypt; $6-1985$ crypt 1 - jade; 2-4-carnelian; 5, 6-amber

эллинистического времени отличаются от более поздних размерами: к раннему времени относятся тонкие цилиндрики высотой 1-2 мм и диаметром 3-4, редко 5-6 мм. В римское же время преобладают более толстые диаметром от 3 до 6, а иногда и до 12 мм. Размерные характеристики рассматриваемых нами бусин (высота 1,5-2,5 мм, диаметр от 3,5 до 6 мм) более соответствуют раннему периоду распространения типа.

\section{Бусы из сердолика}

Среди рассматриваемых бус есть 11 округлых сердоликовых. Все, за исключением одной шаровидной, усеченной дважды, с просверленным с одной стороны отверстием (рис. 5: 2), имеют эллипсоидную, усеченную дважды форму и канал, просверленный с двух сторон (рис. 5: 3, 4). Шаровидная бусина была найдена в отвале кургана 30. Шесть бусин эллипсоидной формы происходят из склепа 1985 г. и по две - из склепа 1984 г. и кургана $31 \mathrm{a}$.

В Северном Причерноморье сердоликовые бусины шаровидной и эллипсоидной 
форм представляют два наиболее распространенных типа. В частности, Е.М. Алексеевой учтено 842 экз. шаровидных и 964 экз. эллипсоидных из всех учтенных ею 2167 сердоликовых бусин. Тип шаровидных зарождается еще в эллинизме, массово распространяется в I-II вв. и доживает до III в. н. э. В ранний период бусины этого типа фиксируются только на Тамани и в Танаисе (Алексеева, 1982, с. 15, 77, табл. 38: 18). Тип эллипсоидных бусин появляется в III в. до н. э., бытует и в римское время. К раннему периоду относятся бусы из светлого и чистого камня, к римскому времени - менее прозрачные, с большим количеством темных прожилок (Алексеева, 1982, с. 16, 77, табл. 38: 29, 30, тип 3б).

Бусы из янтаря

Bсе 5 янтарных бусин из рассматриваемых погребений некрополя относятся к округлым шаровидным, усеченным с двух сторон (рис. 5: 5, 6). Три из них обнаружены в кургане 40, по одной - в склепах 1983 и 1985 гг. В Своде Е.M. Алексеевой учтено 57 аналогичных бусин. Они наиболее характерны для I-III вв. н. э., однако три бусины известны из комплексов Пантикапея, Фанагории и Танаиса, относящихся к IV-II вв. до н. э. (Алексеева, 1978, c. 24,88 , табл. $23: 33,36$, тип 5).

Бусина из горного хрусталя

Единственная горнохрустальная бусина имеет округлую шаровидную, усеченную с двух сторон, асимметричную форму (склеп 1984 г.). Аналогичные ей бусины из Свода Е.М. Алексеевой (ею учтено 102 экз.) появляются в конце II - I в. до н. э. и бытуют до
III в. н. э. с наибольшим распространением в I-II вв. н. э. (Алексеева, 1982, с. 7, 76, табл. 35: 16, 17, тип 2a).

\section{Бусина из кости}

Подобных костяной бусине округлой кольцевидной формы (курган 11) в Северном Причерноморье немного - в Своде Е.М. Алексеевой учтено всего 6 экз., происходящих из комплексов IV-III вв. до н. э. и II-III вв. н. э. (Алексеева, 1982, с. 31, 81, табл. 46: 28, тип 1).

Сопоставление результатов морфо-технологического изучения стеклянных и фаянсовых бус из комплексов некрополя у пос. Заозерное с существующими классификациями стеклоделательных мастерских (Щапова, 1983, с. 139-140) позволяет предположить, что бусы, поступавшие к населению, захороненному в некрополе, были изготовлены в специализированных мастерских с полным или неполным производственным циклом с разделением труда между специалистами. Подобные мастерские выпускали продукцию большими сериями и располагались в районах традиционного стеклоделия: в Египте, Передней Азии, на территории Средиземноморья. По мнению ряда исследователей, такие мастерские были связаны с международной торговлей (Лихтер, Щапова, 1991, с. 247).

Bce рассмотренные нами бусы, как стеклянные и фаянсовые, так и изготовленные из других материалов, адресованные местному населению, являются импортами, достоверно отражающими направления культурных связей и торговых контактов различных территорий.

\section{Примечания:}

${ }^{1}$ Предварительный анализ бусин из трех комплексов (склепы 1984 и 1985 гг. и погребение ребенка 1984 г.) см. в: Столярова, 1993; Столярова, 1997.

${ }^{2}$ Благодарю Е.А. Попову за предоставленную возможность исследовать данный материал.

3 Зачастую бусины из красно-коричневого стекла покрыты толстым слоем коррозии желтого цвета.

${ }^{4}$ Еще одна бусина такой же формы сделана из стекла, цвет которого установить не удалось (склеп 1985 г.) (рис. 4: 26).

\section{ЛИТЕРАТУРА}

Алексеева Е.М. Античные бусы Северного Причерноморья / САИ. Вып. Г1-12 . М: Наука, 1975. 94 c.

Алексеева E.M. Античные бусы Северного Причерноморья / САИ. Вып. Г1-12. М.: Наука, 1978. $104 \mathrm{c.}$

Алексеева Е.М. Античные бусы Северного Причерноморья / САИ. Вып. Г1-12. М: Наука, 1982. $104 \mathrm{c}$.

Дамевская О.Д. Некрополь Беляуса. Симферополь: Предприятие Феникс, 2014. 284 с.

Дзнеладзе Е.С. Бусы из могильника Красный Маяк как хроноиндикатор // Археологія і давня історія Украіни. 2015. Вип. 2. С. 191-201.

Лихтер Ю.А., Щапова Ю.Л. Гнездовские бусы. По материалам раскопок курганов и поселения // Смоленск и Гнездово (к истории древнерусского города) / Под ред. Д.А. Авдусина. М.: МГУ, 1991. C. 244-260. 
Попова Е.А., Пежемский Д.В., Беловинцева Н.И. Городище Чайка, некрополь и каменоломня античной эпохи на окраине Евпатории в Северо-Западном Крыму: итоги и перспективы исследования // Исторические исследования. 2015. № 3. С. 76-112.

Синика В.С., Тельнов Н.П. Скифский курган 116 первой половины III в. до н. э. у с. Глиное // Древности. Исследования и проблемы. Сб. статей в честь 70-летия Н.П. Тельнова / Под ред. В.С. Синики и P.А. Рабиновича. Кишинев; Тирасполь: Stratum Plus, 2018. С. 223-266.

Столярова E.K. Стеклянные и каменные бусы из позднескифских погребений некрополя у городища «Чайка» // Памятники бронзового и железного веков в окрестностях Евпатории / Отв. ред. Ю. Л. Щапова, И. В. Яценко М.: МГУ, 1993. С. 45-62.

Столярова Е.К. Химико-технологическое изучение стеклянных бус из некрополя у пос. Заозерное // Древности Евразии / Отв. ред. С. В. Демиденко, Д. В. Журавлев. М.: ГИМ, 1997. С. 216-226.

Храпунов И.Н., Мульд С.А., Стоянова А.А. Позднескифский склеп из могильника Опушки. Симферополь: Доля, 2009. $96 \mathrm{c.}$

Щапова Ю.Л. Очерки истории древнего стеклоделия (по материалам долины Нила, Ближнего Востока и Европы). М.: МГУ, 1983. 200 с.

Weinberg G. A Hellenistic Glass Factory on Rhodes: Progress Report // Journal of Glass Studies. Vol. 25. 1983. P. 37.

\section{Информация об авторе:}

Столярова Екатерина Карленовна, старший преподаватель кафедры археологии исторического факультета, МГУ имени М.В.Ломоносова (г. Москва, Россия); kath.stoliarova@gmail.com

\section{REFERENCES}

Alekseeva, E. M. 1975. Antichnye busy Severnogo Prichernomor'ia (Ancient Beads of Northern Pontic Region). Series: Svod Arkheologicheskikh Istochnikov (Corpus of Archaeological Sources) GI-12. Moscow: "Nauka" Publ. (in Russian).

Alekseeva, E. M. 1978. Antichnye busy Severnogo Prichernomor'ia (Ancient Beads of Northern Pontic Region). Series: Svod Arkheologicheskikh Istochnikov (Corpus of Archaeological Sources) GI-12. Moscow: "Nauka" Publ. (in Russian).

Alekseeva, E. M. 1982. Antichnye busy Severnogo Prichernomor'ia (Ancient Beads of North Pontic). Series: Svod Arkheologicheskikh Istochnikov (Corpus of Archaeological Sources) GI-12. Moscow: "Nauka" Publ. (in Russian).

Dashevskya, O. D. 2014. Nekropol' Beliausa (The Necropolis of Belyaus). Simferopol: "Predpriiatie Feniks" Publ. (in Russian).

Dzneladze, E. S. 2015. In Arkheologiia i davnia isroriia Ukraini (Archaeology and Ancient History of Ukraine) 2, 191-201 (in Russian).

Likhter, Yu. A., Shchapova, Yu. L. 1991. In Avdusin, D. A. (ed.). Smolensk $i$ Gnezdovo (k istorii drevnerusskogo goroda) (Smolensk and Gnezdovo (the History of an Ancient Russian Town)). Moscow: Moscow State University, 244-260 (in Russian).

Popova, E. A., Pezhemsky, D. V., Belovitseva, N. I. 2015. In Istoricheskie issledovaniya (History Studies) 3. 76-112 (in Russian).

Sinika, V. S., Telnov, N. P. 2018. In Sinika, V. S., Rabinovich, R. A. (eds.). Drevnosti. Issledovaniia $i$ problem (Antiquities. Studies and Issues). Kishinev, Tiraspol: "Stratum plus" Publ., 223-266 (in Russian).

Stolyarova, E. K. 1993. In Shchapova, Yu. L., Yatsenko, I. V. (ed.). Pamiatniki bronzovogo i zheleznogo vekov v okrestnostiakh Evpatorii (Monuments of the Bronze and Iron Ages in the Vicinity of Eupatoria). Moscow: Moscow State University, 45-62 (in Russian).

Stolyarova, E. K. 1997. In Demidenko, S. V., Zhuravlev, D. V. (eds.). Drevnosti Evrazii (Antiquities of Eurasia). Moscow: State Historical Museum, 216-226. (in Russian).

Khrapunov, I. N., Muld, S. A., Stoyanova, A. A. 2009. Pozdneskifskii sklep iz mogil'nika Opushki (Late Scythian Crypt from Opushki Burial Ground). Simferopol: "Dolia" Publ. (in Russian).

Shchapova, Yu. L. 1983. Ocherki istorii drevnego steklodeliia (po materialam doliny Nila, Blizhnego Vostoka $i$ Evropy (Essays on the History of Ancient Glassmaking (on the Materials from the Nile Valley, the Middle East and Europe). Moscow: Moscow Satte University (in Russian).

Weinberg, G. A 1983. In Journal of Glass Studies. Vol. 25, 37.

\section{About the Author:}

Stolyarova Ekaterina K. Lomonosov Moscow State University. Lomonosovskij Prospect 27, korp. 4, Moscow, 119991, Russian Federation;; kath.stoliarova@gmail.com 